\title{
High-level expression and characterization of a novel cutinase from Malbranchea cinnamomea suitable for butyl butyrate production
}

\author{
Xiaojie Duan ${ }^{1,2}$, Yu Liu ${ }^{1,2}$, Xin You $^{1,3}$, Zhengqiang Jiang ${ }^{1,2}$, Shaoxiang Yang ${ }^{4}$ and Shaoging Yang ${ }^{1,2^{*}}$
}

\begin{abstract}
Background: Butyl butyrate has been considered as a promising fuel source because it is a kind of natural ester which can be converted from renewable and sustainable lignocellulosic biomass. Compared with the conventional chemical methods for butyl butyrate production, the enzymatic approach has been demonstrated to be more attractive, mainly owing to the mild reaction conditions, high specificity, low energy consumption, and environmental friendliness. Cutinases play an important role in the butyl butyrate production process. However, the production level of cutinases is still relatively low. Thus, to identify novel cutinases suitable for butyl butyrate synthesis and enhance their yields is of great value in biofuel industry.

Results: A novel cutinase gene (McCut) was cloned from a thermophilic fungus Malbranchea cinnamomea and expressed in Pichia pastoris. The highest cutinase activity of $12,536 \mathrm{U} / \mathrm{mL}$ was achieved in 5 -L fermentor, which is by far the highest production for a cutinase. McCut was optimally active at pH 8.0 and $45^{\circ} \mathrm{C}$. It exhibited excellent stability within the $\mathrm{pH}$ range of $3.0-10.5$ and up to $75^{\circ} \mathrm{C}$. The cutinase displayed broad substrate specificity with the highest activity towards $p$-nitrophenyl butyrate and tributyrin. It was capable of hydrolyzing cutin, polycaprolactone, and poly(butylene succinate). Moreover, McCut efficiently synthesized butyl butyrate with a maximum esterification efficiency of $96.9 \%$ at $4 \mathrm{~h}$. The overall structure of McCut was resolved as a typical $\mathrm{a} / \beta$-hydrolase fold. The structural differences between McCut and Aspergillus oryzae cutinase in groove and loop provide valuable information for redesign of McCut. These excellent features make it useful in biosynthesis and biodegradation fields.
\end{abstract}

Conclusions: A novel cutinase from M. cinnamomea was identified and characterized for the first time. High-level expression by $P$. pastoris is by far the highest for a cutinase. The enzyme exhibited excellent stability and high esterification efficiency for butyl butyrate production, which may make it a good candidate in biofuel and chemical industries.

Keywords: Cutinase, Malbranchea cinnamomea, High-level expression, Stability, Butyl butyrate, Crystal structure

\section{Background}

With the increasing gradual energy consumption, depletion of fossil fuel, and growing environmental awareness, development of alternative renewable energy sources has received considerable attention [1-3]. Short-chain

\footnotetext{
*Correspondence: ysq@cau.edu.cn

${ }^{1}$ Beijing Advanced Innovation Center for Food Nutrition and Human Health, China Agricultural University, Beijing 100083, China

Full list of author information is available at the end of the article
}

butyrate esters have been considered as potential replacements for aviation kerosene, mineral diesel, or petrol recently because they are natural esters which can be converted from renewable and sustainable lignocellulosic biomass [2]. Among them, butyl butyrate has been accepted as a better alternative as it was found to have some special properties, such as high boiling point, low viscosity, low-temperature behavior, and good miscibility with other fuels $[2,4,5]$. 
The conventional chemical method for butyl butyrate production has some disadvantages, including high energy consumption, hazardous conditions, and release of a large amount of environmental pollutants [5, 6]. Recently, an enzymatic approach for butyl butyrate production has been developed and further demonstrated to be more promising than those chemical routes, mainly owing to the mild reaction conditions, high specificity, low energy consumption, and environmental friendliness [5]. In the bioconversion process, lipases have been used as the major enzymes for the synthesis of butyl butyrate [4-7]. However, cutinases may be more suitable and effective in butyl butyrate synthesis since they typically show preference for short-chain length substrates, while lipases usually have higher affinity for long-chain substrates [8]. Hence, the identification of novel cutinases suitable for butyl butyrate production is of great value.

Cutinases (EC 3.1.1.74) are the smallest member of $\alpha / \beta$ hydrolase family, capable of catalyzing not only hydrolysis reactions, but also esterification and transesterification reactions [9]. So far, a number of cutinases have been investigated from fungi and bacteria [9]. In general, enzymes from thermophilic microorganisms display relatively high optimal temperature and good thermostability compared to those from mesophilic microorganisms. However, there are few reports on cutinases from thermophilic fungi, except for Humicola insolens [10] and Thielavia terrestris $[11,12]$. Although many cutinase genes have been cloned and expressed, few reports are available on bioreactor systems for large-scale production $[8,13-16]$. Additionally, the production level of cutinases is still relatively low. The Thermobifida fusca cutinase expressed in Escherichia coli represented the highest yield ever reported, with an activity of $2258.5 \mathrm{U} /$ $\mathrm{mL}$ and a protein concentration of $5.1 \mathrm{~g} / \mathrm{L}$ [16]. To meet the needs of industrial applications and reduce production cost, high-level expression of cutinases is urgent and necessary. Pichia pastoris is an excellent protein expression host, which has been widely used for the production of various proteins, including industrial enzymes [17], and human interferon gamma $[18,19]$. However, no cutinase gene has been ever highly expressed in P. pastoris suitable for commercial production.

Up to now, three-dimensional structures of several cutinases have been deposited in the Protein Data Bank, including six fungal and two bacterial cutinases. The crystal structure of the cutinase from Fusarium solani pisi was firstly determined and thoroughly studied [20, 21]. Structures of fungal cutinases from Aspergillus oryzae [22], Fusarium oxysporum [23], Glomerella cingulata [24], H. insolens [10], and Trichoderma reesei [25], and two bacterial cutinases from Thermobifida alba [26] and T. fusca [27] have been solved. Structural studies of cutinases can help further understand their action modes and obtain more useful information for the redesign of enzymes to fulfill industrial application requirements.

The thermophilic fungus, Malbranchea cinnamomea S168, has been found to produce glycoside hydrolases such as $\alpha$-amylase and xylanase [28, 29]. The secretome analysis showed that $M$. cinnamomea produced cutinase [30]. However, no cutinase from M. cinnamomea has been ever studied. In this paper, a novel cutinase gene $(\mathrm{McCut})$ from M. cinnamomea S168 was cloned and efficiently expressed in P. pastoris. The recombinant cutinase was purified, biochemically and structurally characterized, and its application in butyl butyrate synthesis was further investigated.

\section{Results}

\section{Cloning and sequence analysis of a cutinase gene from $M$. cinnamomea}

A cutinase gene (McCut) was amplified from cDNA, and it contains an open reading frame of $648 \mathrm{bp}$, encoding 215 amino acids. There are two introns of 61 and $108 \mathrm{bp}$, respectively, in the cutinase gene. The mature protein has a predicted molecular mass of $21,180 \mathrm{Da}$ and a theoretical $p \mathrm{I}$ of 5.19. The $\mathrm{N}$-terminal region contained a predicted signal peptide of 16 amino acids, and the protein sequence did not have $N$-glycosylation site. The gene sequence has been submitted to GenBank under the Accession Number KY568910.1.

Sequence analysis revealed that McCut contained a catalytic triad consisting of Ser128, Asp183, and His196. According to the sequence similarity analysis, the deduced amino acid sequence of McCut shared the highest identity of $65 \%$ with the cutinase from Aspergillus nidulans (Q5AVY9.2), followed by cutinases from A. oryzae (63\%, 3GBS_A), Aspergillus niger (59\%, AKE48475.1), H. insolens (54\%, 4OYY_A), and Colletotrichum gloeosporioides (53\%, AAL38030.1) (Fig. 1).

\section{Expression of the cutinase gene in P. pastoris by high-cell density fermentation}

The cutinase (McCut) was expressed in P. pastoris under the $A O X 1$ promoter. A transformant showing the highest cutinase activity in shake-flask was screened out from YPD plates with a geneticin 418 (G418) concentration of $1 \mathrm{mg} / \mathrm{mL}$ and cultivated in a 5 - $\mathrm{L}$ fermentor. A maximum activity of $12,536 \mathrm{U} / \mathrm{mL}$ was achieved after $132 \mathrm{~h}$, with a protein content of $10.8 \mathrm{~g} / \mathrm{L}$ and a dry cell weight $(\mathrm{dcw})$ of $86.3 \mathrm{~g} / \mathrm{L}$ (Fig. 2a). It resulted in the yields of 77, $846 \mathrm{U} / \mathrm{g}$ $\mathrm{dcw}$ and 14, $500 \mathrm{U} / \mathrm{g}$ methanol. Furthermore, the recombinant cutinase was slightly cell wall localized (about $4 \%$ of the supernatant activity). From the SDS-PAGE analysis, a very less amount of other proteins was secreted into the medium (Fig. 2b). 


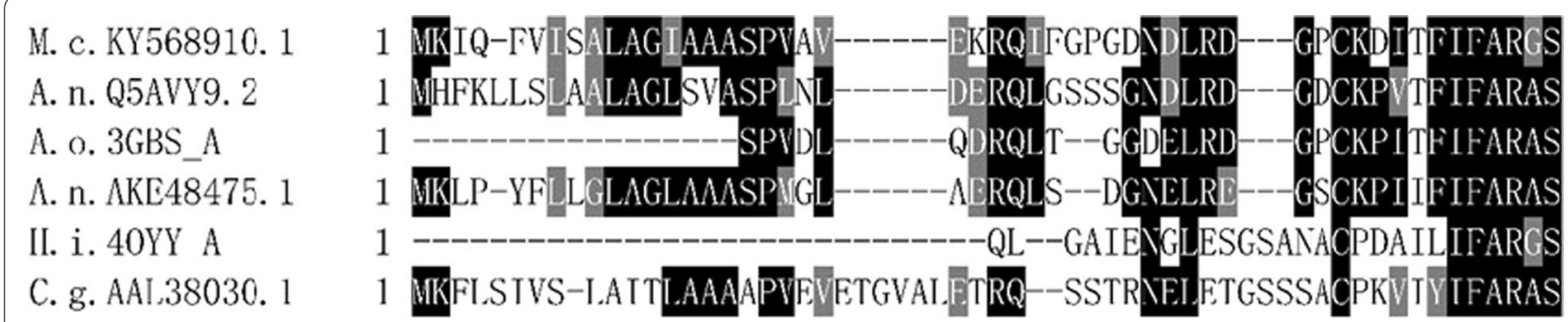

M. c. KY568910. 151 TEPGLMGITVGPDTCDLLNRE-FRGRVACQGVGPRYEASLAGNFLPRGTTQAAIDEAAEL A. n. Q5AVY9. 2

A. O. 3GBS_A

52 TEPGLLGISTGPAVCNDLKADASLGGVACQGVGPKYTAGLAENALPQGTSSAAINEAKEL

A. n. NKE48475. 1

H. i. 40YY_A

33 TEPGL GTSTGPAVCNRLKLLA-RSGDVACQGVGPRYTADLPSIALPEGTSQAATAEAQGI.

49 TEPGLLGISTGPAVCNJLKUA-KAGQVLCQGVGPAYTADLWSWLPDNTSPMISESESL

C. g. AAL38030. 1

29 TEPGN GITVGPALANGLESH--IRNIWIQGVGGPYDAALATNFLPRGTSQANIDEGKRL 58 TEPGNGGISAGPTVADALERIYGANDVWVQGVGGPYLADLASNFLPDGTSSAATNEARRL

M. c. KY568910. 1 110 FNLAHTKCPNTQIVGGGYSQGAAVMIGATPGLSNAVKDQTKGVVLYGDTRNEQDGGRIPN A. n. Q5AVY9. 2112 FELAASKCPDTRIVAGGYSQGTAVMHGAIPDLSDETKDKIAGVVLFGDTRNKQDGGQIKN A. o. 3GBS_A 92 FEQAVISKCPDTQTVAGGYSQGTAVMNGATKRL SADVQDKTIKGVVI.FGYTRNAQERGQTAN A. n. AKE48475. 1 108 FKLMSKCPNSQILAGGYSQGTAVMDDSIKQLPDDVKDKIKGVVLFGYTRNAQLGGQIGN H. i. 40YY_A 87 FALANQKCPNTPVVAGGYSQGAALIAAAVSELSGAVKEQVKGVALFGYTQNLQNRGGIPN C. g. AAL38030. 1118 FTLANIKCPNAAIVSGGYSQGTAVMAGSISGLSTTIKNQIKGVVLFGYTKNLQNLGRIPN

M. c. KY568910. 1 170 FPTDKTNIICNPGLVCDGTLILTAAIIFTYGTRVR-GAVD LEDRLS-

A. n. Q5AVY9. 2172 FPKDKIKIYCATGDLVCDGTLVVTAAHFTYVANTG-EASKMLEQLASYPASTSTSSSSS A. o. 3GBS_A 152 FPKDKVKVYCAVGDLVCLGTLTVAPPHFSYLSDTG-DASDFLLSQL.

A. n. AKE48475. 1168 FPKDKVKIYCAMGDLVCDGTLIVTMAHFTYVMNTG-EASQ LESKLSDTTTSSLTGSSSS II. i. 40YY_A 147 YPRERTKVFGNGDAVCTGTLIITPAILSYTIEARGEAAR LRDRIRA-

C. g. AAL38030. 178 FETSKTEVYCDIADAVCYGTLFILPAHFLYQTDAAVAAPRFLQARIC

M. c. KY568910. 1

A. n. Q5AVY9. 2

231 SSSSAPA-----SQTSQSSGLS--SWFSGLGN-

A. o. 3GBS_A

A. n. AKE48475. 1227 DTSSSTSTGDSSSESSSTAGLGGLSGLTGLGSSTSGGFPSLASLF

H. i. 40YY_ $\Lambda$

C. g. AAL38030. 1

Fig. 1 Multiple alignment of amino acid sequences of McCut with homologous cutinases. Numbers on the left are the residue number of the first amino acid in each line. The putative catalytic triad (denoted by stars below the residues) of McCut was predicted by alignment with structureresolved A. oryzae cutinase (PDB ID: 3GBS_A). Abbreviations and GenBank Accession Numbers or PDB ID of the cutinases in the alignment are as follows: M. cinnamomea S168 (M.c.KY568910.1), A. nidulans FGSC A4 (A.n.Q5AVY9.2), A. oryzae (A.o.3GBS_A), A. niger (A.n.AKE48475.1), H. insolens (H.i.4OYY_A), and Colletotrichum gloeosporioides (C.g.AAL38030.1). Identical residues are shaded in black, and conserved residues are shaded in gray 


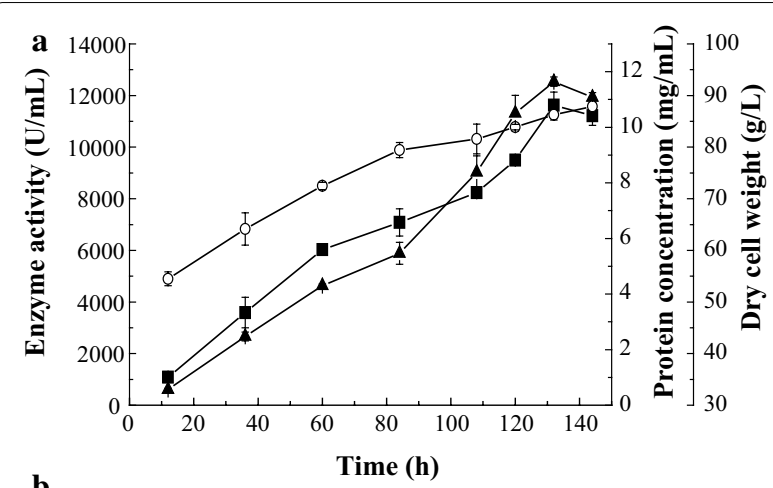

b

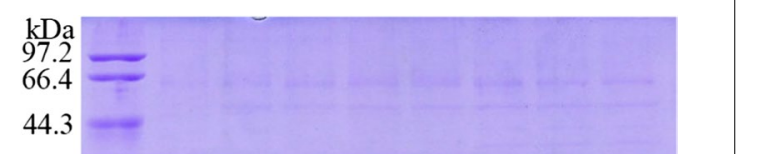

29.0

20.1

14.4
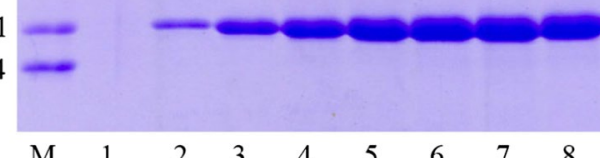

c

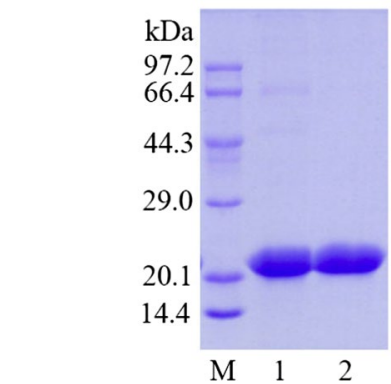

Fig. 2 Time course of recombinant cutinase produced by P. pastoris in a 5-L fermentor (a), and SDS-PAGE analysis of expression (b) and purification steps (c). The enzyme activity (filled triangle) and protein concentration (filled square) were monitored during high-cell density cultivation. The cutinase activity was determined at $45^{\circ} \mathrm{C}$ in $50 \mathrm{mM}$ Tris- $\mathrm{HCl}$ (pH 8.0) using pNPB as the substrate. All data are mean values of triplicate measurements. In $\mathbf{b}$, lane M: low-molecular weight standard protein markers; lane 1: before methanol induction; lanes 2-8: culture supernatant collected after 12, 36, 60, 84, 108, 120, 132, and $144 \mathrm{~h}$ of methanol induction, respectively. In c, lane M: lowmolecular weight standards; lane 1: crude enzyme; lane 2: purified enzyme

\section{Purification of the recombinant cutinase}

McCut was purified to apparent homogeneity by a single step of ion-exchange chromatography using Q Sepharose Fast Flow (QSFF) with a specific activity of 1, $181.6 \mathrm{U} /$ $\mathrm{mg}$ and a recovery yield of $88.3 \%$. The purified enzyme showed a single band in SDS-PAGE with a molecular mass of $21.9 \mathrm{kDa}$ (Fig. 2c), which matches with the predicted molecular mass of $21.18 \mathrm{kDa}$.

\section{Crystal structure of McCut}

The crystal structure of McCut was determined at 1.76 $\AA$ resolution in space group $P 22_{1} 22_{1}$. The $R_{\text {work }}$ and $R_{\text {free }}$ were 17.17 and $17.54 \%$, respectively. The crystallographic asymmetric unit contains one protein molecule. McCut is an $\alpha / \beta$ hydrolase with a central $\beta$-sheet of five parallel strands surrounded by nine $\alpha$-helices (Fig. 3a). The active site of mature protein is composed of the catalytic triad Ser112, Asp167, and His180 (Fig. 3b), which is in accordance with the aforementioned result. There are two disulfide bonds in the cutinase, one between cysteines 49 and 62 and the other linking cysteines 23 and 101 (Fig. 3c).

Superimposition of the structures of McCut, A. oryzae cutinase (AoCut, PDB code: 3GBS), F. solani cutinase (FsCut, PDB code: 1CEX), cutinase-like enzyme from Cryptococcus sp. S-2 (CLE, PDB code: 2CZQ), and G. cingulata cutinase (PDB code: $3 \mathrm{DCN}$ ) reveals that the overall fold is almost identical (Fig. 4a). The minor difference between McCut and the others can be seen in the loop region (Fig. 4a). The side chains of Ser34 and Phe181 extend to the catalytic groove leading to the space steric hindrance (Fig. 4b). Moreover, two gatekeeper residues, Leu73 and Leu176, in McCut are 7.2 $̊$ apart, whereas the corresponding residues (Leu87 to Val190) of AoCut are separated by $9.2 \AA$ (Fig. 4c). This suggests that McCut has a narrower catalytic cleft.

\section{Biochemical properties of McCut}

The optimal $\mathrm{pH}$ of $\mathrm{McCu}$ was found to be $\mathrm{pH} 8.0$ (Fig. 5a). It was stable in a broad $\mathrm{pH}$ range from $\mathrm{pH} 3.0$ to 10.5 (Fig. 5b). McCut displayed maximal activity at $45^{\circ} \mathrm{C}$ (Fig. $5 \mathrm{c}$ ). It retained more than $85 \%$ of its initial activity after incubation at $75{ }^{\circ} \mathrm{C}$ for $30 \mathrm{~min}$ (Fig. 5d). Specially, approximately $47.5 \%$ of its activity was maintained after incubation at $100{ }^{\circ} \mathrm{C}$ for $30 \mathrm{~min}$ (Fig. 5d). The half-lives of McCut at $70,75,80$, and $85^{\circ} \mathrm{C}$ were $263,160,92$, and 67 min, respectively (Fig. 5e).

The influence of different organic solvents on enzyme activity was investigated (Table 1). Short-chain alcohols and acids inhibited the enzyme activity to different degrees. McCut was hardly affected by hexane and isooctane, but enhanced by cyclohexane (127.9\%), $n$-heptane (131.3\%), and $n$-octane (143.5\%). However, the activity was slightly inhibited by acetone, dimethyl sulfoxide, and acetonitrile.

All the tested surfactants including Tween 20, Tween 40, Tween 60, Tween 80, Triton X-100, and SDS activated the enzyme activity (Table 1 ). Triton X-100 was found to greatly enhance the enzyme activity to $190.1 \%$ (Table 1 ). 

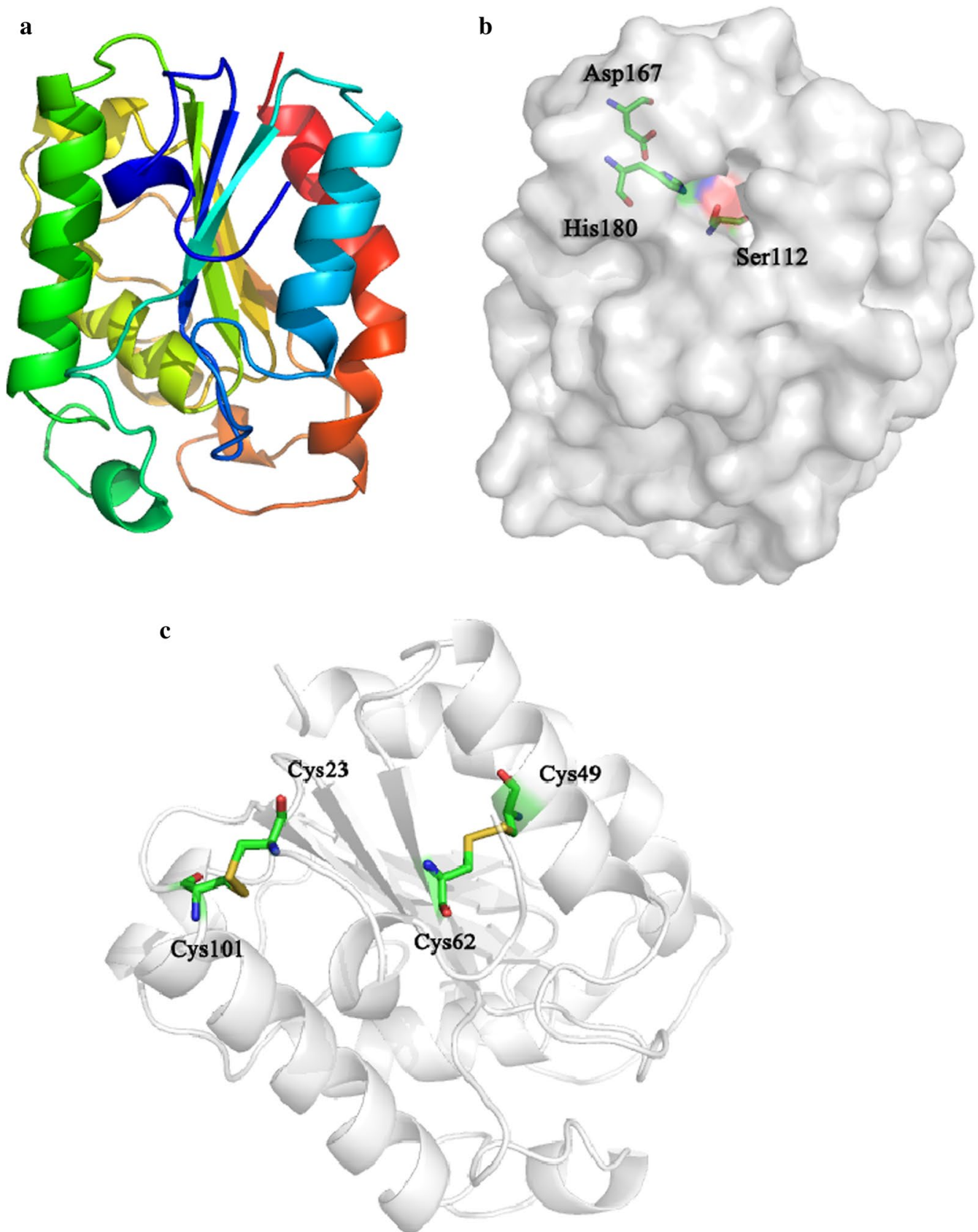

Fig. 3 Overall structure of McCut. a Overall structure of McCut in the form of a cartoon. It contains five parallel strands and nine $a$-helices. $\mathbf{b}$ The molecule with three catalytic sites Ser112, Asp167, and His180 is shown as a surface. c Two disulfide bonds between Cys49 and Cys62, and Cys23 and Cys 101 are displayed

\section{Substrate specificity and kinetic parameters of McCut}

The substrate specificity of McCut was investigated using $p$-nitrophenol ( $p \mathrm{NP})$ esters and triglycerides with acyl chain lengths ranging from $\mathrm{C}_{2}$ to $\mathrm{C}_{16}$ (Table 2). The highest specific activity was observed with $\mathrm{C}_{4}$ substrates, $p$-nitrophenyl butyrate $(p \mathrm{NPB})$, and tributyrin, showing the specific activity of 1147.9 and $361.1 \mathrm{U} /$ mg, respectively. It efficiently hydrolyzed $p$-nitrophenyl hexanoate $(p \mathrm{NPH})$, which is slightly weaker than that of $p \mathrm{NPB}$, and its activities for these substrates did not decrease as the acyl chain lengths increase from 8 to 16 . In contrast, substrate specificity of McCut towards triglycerides showed a different trend. The enzyme activity declined sharply with the increase of acyl chain 

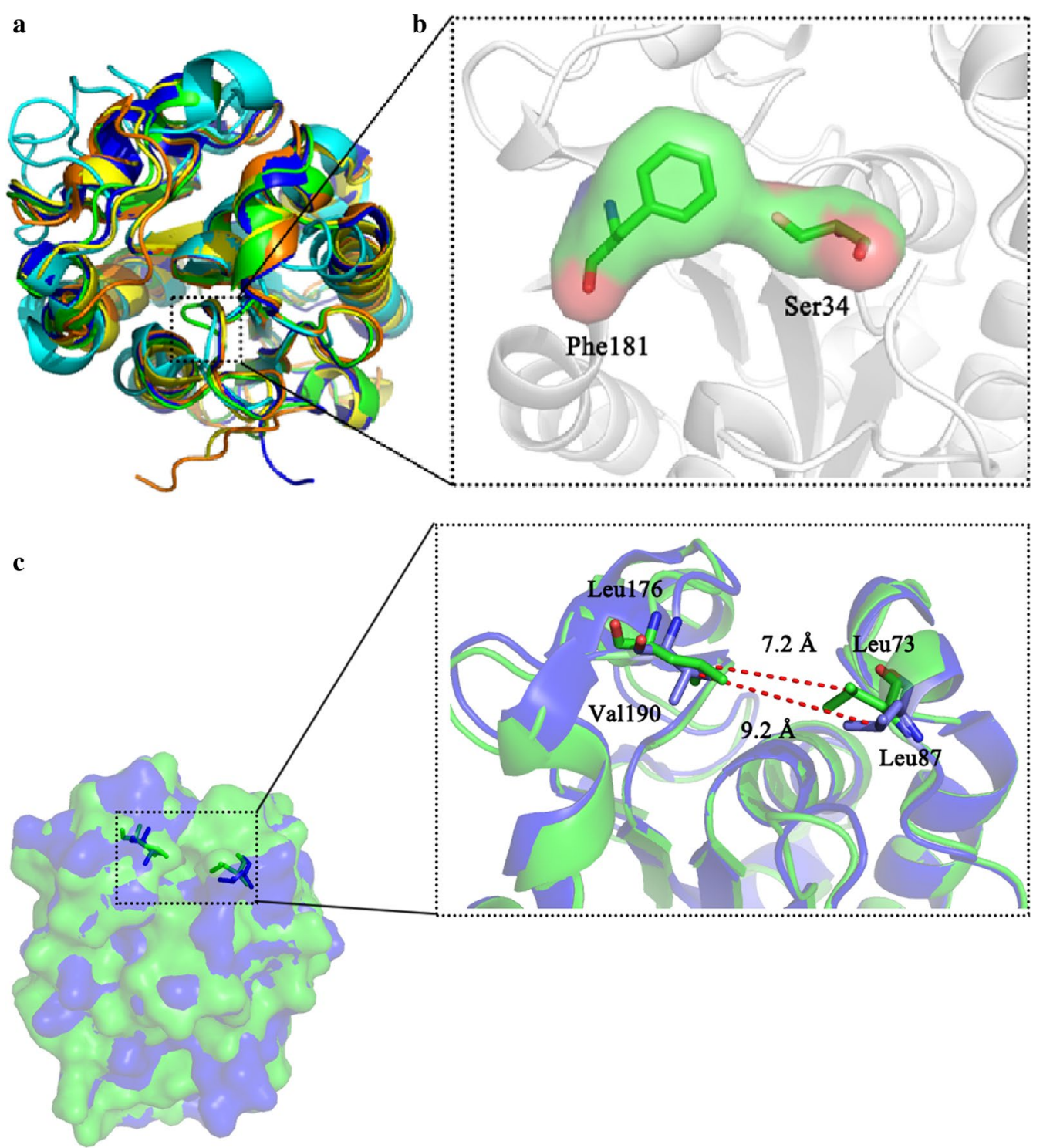

Fig. 4 Structural comparison of McCut and other cutinases. a Superposition of McCut on other cutinases is shown by ribbon diagram, with ribbons colored according to each enzyme: McCut in green, AoCut (PDB code: 3GBS) in blue, FsCut (PDB code: 1CEX) in yellow, CLE (PDB code: 2CZQ) in cyan, and G. cingulata cutinase (PDB code: $3 D C N$ ) in orange. $\mathbf{b}$ The unique loop is further shown as a cartoon in the comparison structure. The difference of Ser34 in McCut leads to the space steric hindrance. cThe gatekeeper residues Leu73 and Leu176 in McCut, and Leu87 and Val190 in AoCut are shown

lengths, and almost negligible activity was detected with $\mathrm{C}_{14}$ and $\mathrm{C}_{16}$ triglycerides. McCut displayed better binding affinity towards $p \mathrm{NPH}\left(K_{\mathrm{m}}=0.27 \mathrm{mM}\right)$ than $p \mathrm{NPB}$ $\left(K_{\mathrm{m}}=0.66 \mathrm{mM}\right)$, while the catalytic constant $\left(k_{\mathrm{cat}}\right)$ was the same for $p \mathrm{NPH}$ and $p \mathrm{NPB}$, which was $0.46 \mathrm{~s}^{-1}$.

\section{Degradation of polymers by McCut}

McCut could degrade cutin with a hydrolytic rate of $4.88 \mu \mathrm{mol} / \mathrm{h} / \mathrm{mg}$ protein. Moreover, it hydrolyzed aliphatic polyesters polycaprolactone (PCL) and poly(butylene succinate) (PBS) with the weight losses of 55.8 and $41.3 \%$ at $12 \mathrm{~h}$, respectively (Table 3 ). However, McCut could not degrade aromatic polyester polyethylene terephthalate (PET).

\section{Synthesis of butyl butyrate by McCut}

Different dosages $(200-600 \mathrm{U} / \mathrm{mL})$ of the cutinase were used in the synthesis of butyl butyrate (Fig. 6a). It took 


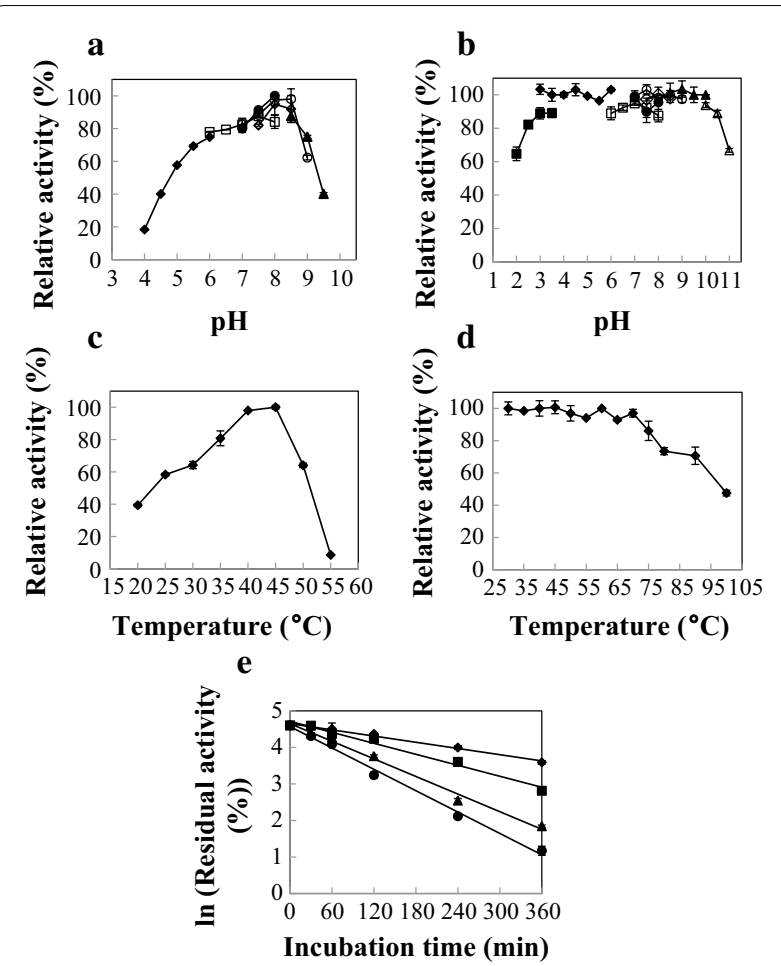

Fig. 5 Optimal pH (a), pH stability $(\mathbf{b})$, optimal temperature $(\mathbf{c})$, thermostability (d), and thermal denaturation half-lives (e) of McCut. The optimal $\mathrm{pH}$ was determined at $45^{\circ} \mathrm{C}$ in $50 \mathrm{mM}$ of different buffers. To determine $\mathrm{pH}$ stability, the enzyme was incubated in various buffers at $50^{\circ} \mathrm{C}$ for $30 \mathrm{~min}$, and the residual activity was measured. Buffers used were as follows: glycine- $\mathrm{HCl}$ (filled square), $\mathrm{pH}$ 2.0-3.5; citrate (filled diamond), pH 3.0-6.0; phosphate (open square), pH 6.0-8.0; Tris- $\mathrm{HCl}$ (open circle), pH 7.0-9.0; HEPES (filled circle), pH 7.0-8.0;

Tricine (open diamond), pH 7.5-8.5; CHES (filled triangle), $\mathrm{pH}$ 8.0-10.0; and CAPS (open triangle), pH 10.0-11.0. For optimal temperature, the enzyme activity was assayed at temperatures ranging from 20 to $55^{\circ} \mathrm{C}$ in $50 \mathrm{mM}$ Tris- $\mathrm{HCl}(\mathrm{pH} \mathrm{8.0)}$. The thermostability was investigated by incubating the enzyme at $30-100^{\circ} \mathrm{C}$ in $50 \mathrm{mM}$ Tris- $\mathrm{HCl}(\mathrm{pH}$ 8.0) for $30 \mathrm{~min}$. The residual activity was measured as described in the "Methods" section. For determination of thermal denaturation halflives, McCut was incubated at different temperatures in $50 \mathrm{mM}$ Tris$\mathrm{HCl}(\mathrm{pH}$ 8.0) for $6 \mathrm{~h}$, and the residual activities at different time points were measured. The temperatures used were $70^{\circ} \mathrm{C}$ (filled diamond), $75^{\circ} \mathrm{C}$ (filled square), $80^{\circ} \mathrm{C}$ (filled triangle), and $85^{\circ} \mathrm{C}$ (filled circle). All data are mean values of triplicate measurements

shorter time to reach equilibrium at higher enzyme dosage. The highest esterification efficiency of $96.9 \%$ was achieved at $4 \mathrm{~h}$ using a cutinase dosage of $400 \mathrm{U} / \mathrm{mL}$, with the initial rate of $507.8 \mu \mathrm{mol} / \mathrm{h} / \mathrm{mg}$ protein. Surprisingly, the reaction temperature had little influence on butyl butyrate synthesis by $\mathrm{McCut}$ from 40 to $70{ }^{\circ} \mathrm{C}$, with a slightly higher esterification efficiency at $50{ }^{\circ} \mathrm{C}$ (Fig. 6b). McCut did not lose enzyme activity after incubation at $50{ }^{\circ} \mathrm{C}$ for $2 \mathrm{~h}$, and it retained $87.7 \%$ of its initial activity after incubation for $4 \mathrm{~h}$.
Table 1 Effect of organic solvents and surfactants on the enzyme activity of McCut

\begin{tabular}{lcc}
\hline Solvent & Specific activity (U/mg) & Relative activity (\%) \\
\hline Organic solvent (30\%) & & 100 \\
Control & $1115.4 \pm 11.5$ & 79.9 \\
Methanol & $891.6 \pm 4.6^{\mathrm{a}}$ & 72.8 \\
Ethanol & $811.6 \pm 43.9^{\mathrm{a}}$ & 81.5 \\
Isopropanol & $908.8 \pm 40.4^{\mathrm{a}}$ & 58.8 \\
Butanol & $656.4 \pm 16.2^{\mathrm{a}}$ & 58.2 \\
Acetic acid & $649.1 \pm 17.3^{\mathrm{a}}$ & 35.7 \\
Butyric acid & $398.3 \pm 18.5^{\mathrm{a}}$ & 97.7 \\
$n$-Hexane & $1090.1 \pm 35.8$ & 127.9 \\
Cyclohexane & $1426.6 \pm 32.8^{\mathrm{a}}$ & 131.3 \\
$n$-Heptane & $1465.0 \pm 11.6^{\mathrm{a}}$ & 143.5 \\
Octane & $1601.1 \pm 8.2^{\mathrm{a}}$ & 97.7 \\
Isooctane & $1089.3 \pm 39.3$ & 88.1 \\
Acetone & $983.1 \pm 6.9^{\mathrm{a}}$ & 80.9 \\
Dimethyl sulfoxide & $902.3 \pm 33.5^{\mathrm{a}}$ & 93.1 \\
Acetonitrile & $1038.1 \pm 7.7^{\mathrm{a}}$ & \\
Surfactant (5\%) & & 118.0 \\
Tween 20 & $1316.1 \pm 39.3^{\mathrm{a}}$ & 139.7 \\
Tween 40 & $1557.9 \pm 55.4^{\mathrm{a}}$ & 139.5 \\
Tween 60 & $1555.7 \pm 81.4^{\mathrm{a}}$ & 141.9 \\
Tween 80 & $1582.4 \pm 20.8^{\mathrm{a}}$ & 190.1 \\
Triton X-100 & $2120.9 \pm 40.8^{\mathrm{a}}$ & 131.7 \\
SDS & $1468.6 \pm 44.6^{\mathrm{a}}$ & \\
\hline Thenzyewas & & \\
\hline
\end{tabular}

The enzyme was incubated with various organic solvents and surfactants at $50^{\circ} \mathrm{C}$ for $1 \mathrm{~h}$ in $50 \mathrm{mM}$ Tris- $\mathrm{HCl} \mathrm{pH} \mathrm{8.0,} \mathrm{and} \mathrm{the} \mathrm{residual} \mathrm{activity} \mathrm{was} \mathrm{measured}$ according to the standard method. All data are mean values \pm standard deviations of triplicate measurements

a The difference is significant compared with the control $(P<0.05)$

\section{Discussion}

Cutinases have attracted great interest in recent years due to their great application potential in different fields, including biodiesel production, ester synthesis, textile, and detergent as well as environmental industries [9, 31]. So far, many cutinases have been cloned and expressed to meet industrial requirements for large-scale production [8, 13-16]. However, expression levels of cutinases are generally low. Here we first cloned a novel cutinase gene $(\mathrm{McCu})$ from a thermophilic fungus $M$. cinnamomea and successfully over-expressed in P. pastoris. Since the yeast is adaptable for large-scale fermentation for the production of recombinant proteins, high-cell density fermentation was carried out in a 5-L fermentor. The cutinase activity reached a maximum of $12,536 \mathrm{U} / \mathrm{mL}$ with a protein concentration of $10.8 \mathrm{~g} / \mathrm{L}$. Many cutinases from Alternaria brassicicola [32], A. niger [33], G. cingulata [15], and Sirococcus conigenus [34] have been expressed in P. pastoris. Among those, the production yield of G. cingulata cutinase is the highest, with a protein 
Table 2 Substrate specificity of McCut

\begin{tabular}{|c|c|c|}
\hline Substrate & Specific activity (U/mg) & Relative activity (\%) \\
\hline \multicolumn{3}{|l|}{ pNP esters ${ }^{a}$} \\
\hline$p \operatorname{NPA}\left(C_{2}\right)$ & $553.5 \pm 2.5^{\mathrm{EF}}$ & 48.2 \\
\hline$p N P B\left(C_{4}\right)$ & $1147.9 \pm 8.3^{\mathrm{A}}$ & 100 \\
\hline$p \mathrm{NPH}\left(\mathrm{C}_{6}\right)$ & $1076.2 \pm 5.0^{B}$ & 93.7 \\
\hline$p N P C\left(C_{8}\right)$ & $646.9 \pm 33.3^{D}$ & 56.3 \\
\hline$p \operatorname{NPD}\left(\mathrm{C}_{10}\right)$ & $607.6 \pm 28.3^{D E}$ & 52.9 \\
\hline$p N P L\left(C_{12}\right)$ & $494.5 \pm 5.0^{F}$ & 43.1 \\
\hline$p \operatorname{NPM}\left(\mathrm{C}_{14}\right)$ & $962.6 \pm 5.0^{c}$ & 83.8 \\
\hline$p \operatorname{NPP}\left(\mathrm{C}_{16}\right)$ & $619.5 \pm 10.8^{\mathrm{DE}}$ & 54.0 \\
\hline \multicolumn{3}{|l|}{ Triglycerides $^{b}$} \\
\hline Triacetin $\left(C_{2}\right)$ & $183.6 \pm 4.8^{B}$ & 50.8 \\
\hline Tributyrin $\left(C_{4}\right)$ & $361.1 \pm 11.6^{A}$ & 100 \\
\hline Tricaproin $\left(C_{6}\right)$ & $175.7 \pm 9.1^{\mathrm{B}}$ & 48.7 \\
\hline Tricaprylin $\left(\mathrm{C}_{8}\right)$ & $30.7 \pm 2.9^{C}$ & 8.5 \\
\hline Tricaprin $\left(C_{10}\right)$ & $10.2 \pm 0.5^{D}$ & 2.4 \\
\hline Trilaurin $\left(\mathrm{C}_{12}\right)$ & $7.9 \pm 0.4^{\mathrm{D}}$ & 2.2 \\
\hline
\end{tabular}

All data are mean values \pm standard deviations of triplicate measurements

Mean values associated with different capital letters are siginificantly different within $p N P$ esters or triglycerides

a Activities of McCut towards $p N P$ esters were measured at $45^{\circ} \mathrm{C}$ in $50 \mathrm{mM}$ Tris- $\mathrm{HCl} \mathrm{pH} 8.0$

b Activities with triglycerides as substrates were performed at $45^{\circ} \mathrm{C}$ in $2.5 \mathrm{mM}$ Tris- $\mathrm{HCl}$ pH 8.0 containing $0.1 \%(\mathrm{w} / \mathrm{v})$ Triton $\mathrm{X}-100$ and $0.1 \%(\mathrm{w} / \mathrm{v})$ arabic gum

Table 3 Degradation of polyesters by McCut

\begin{tabular}{llcc}
\hline Polyester & \multicolumn{3}{l}{ Degradation of weight loss percent (\%) } \\
\cline { 2 - 4 } & $\mathbf{3} \mathbf{h}$ & $\mathbf{6} \mathbf{h}$ & $\mathbf{1 2} \mathbf{~}$ \\
\hline $\mathrm{PCL}$ & $13.0 \pm 0.8$ & $48.1 \pm 0.1$ & $55.8 \pm 3.9$ \\
$\mathrm{PBS}$ & $7.2 \pm 0.3$ & $20.0 \pm 0.3$ & $41.3 \pm 0.6$
\end{tabular}

The reaction was carried out at $45^{\circ} \mathrm{C}$ in $100 \mathrm{mM}$ Tris- $\mathrm{HCl} \mathrm{pH} \mathrm{8.0.} \mathrm{The} \mathrm{weight}$ loss of polyesters was measured after degradation. All data are mean values \pm standard deviations of triplicate measurements

concentration of $3.8 \mathrm{~g} / \mathrm{L}$ and an enzyme activity of $434 \mathrm{U} /$ $\mathrm{mL}$ [15], which are much lower than those observed in this study. Some cutinases expressed in other hosts were also performed in bioreactor systems for scale-up production $[8,13,14,16]$. The cutinase gene from T. fusca was expressed in $E$. coli with a yield of $5.1 \mathrm{~g} / \mathrm{L}$ cutinase $(2,258.5 \mathrm{U} / \mathrm{mL})$ in a 3-L fermentor, which is the highest activity level ever reported [16]. Overall, the production level reported in this study represents the highest activity for a cutinase to date, making McCut a potential cutinase for industrial-scale production.

The optimal $\mathrm{pH}$ of McCut ( $\mathrm{pH}$ 8.0) is similar to those of some microbial cutinases $[8,32,35]$, but is higher than those of acidic fungal cutinases, such as those from $T$. terrestris CAU709 ( $\mathrm{pH} 4.0)$ [11, 12], A. niger ( $\mathrm{pH}$ 5.0-6.5) [33], and S. conigenus (pH 4.1-5.2) [34]. Most alkaline cutinases display stability under near-neutral or alkaline conditions [32], whereas McCut showed excellent stability over a wider $\mathrm{pH}$ range from acidic to alkaline. Its stability in acidic $\mathrm{pH}$ values is desirable in ester hydrolysis as the $\mathrm{pH}$ of the reaction system tends to decrease with the release of acids. The optimal temperature of McCut $\left(45^{\circ} \mathrm{C}\right)$ is higher than that of most mesophilic fungal cutinases $[8,15,32]$, but lower than those of cutinases from $T$. terrestris $\left(50\right.$ and $\left.55^{\circ} \mathrm{C}\right)[11,12]$ and $A$. nidulans $\left(60{ }^{\circ} \mathrm{C}\right)$ [36] as well as $T$. fusca $\left(60{ }^{\circ} \mathrm{C}\right)$ [35]. Interestingly, the cutinase exhibited excellent thermostability up to $75{ }^{\circ} \mathrm{C}$. Notably, it retained $47.5 \%$ of its activity after treatment at $100{ }^{\circ} \mathrm{C}$ for $30 \mathrm{~min}$. McCut is much more thermostable than most cutinases, such as those from A. oryzae [22], A. nidulans [36], F. solani [22], G. cingulata [15], T. alba [37], T. fusca [27], and T. terrestris [11, 12]. McCut had a half-life of $67 \mathrm{~min}$ at $85^{\circ} \mathrm{C}$, which is comparable to that of the cutinase from $H$. insolens [38]. The overall structure of McCut showed a low B-factor (13.44), indicating high rigidity of the structure. Furthermore, disulfide bridges are usually believed to make considerable contributions to protein stability $[39,40]$. Like cutinases from G. cingulata [22], F. oxysporum [23], and F. solani [21], McCut has two disulfide bonds, while AoCut has three disulfide bonds [22]. However, McCut exhibited better thermostability than AoCut [22], suggesting that the disulfide bridges may not be the only reason for its thermostability. Rigidifying flexible sites through introduction of prolines is an approach to improve thermostability of proteins by decreasing the entropy of the unfolded state [40], and it has been successfully used to enhance the thermostability of proteins including cutinases [37, 41, 42]. Structure analysis revealed that most of prolines in McCut are located in the flexible loop regions (except Pro46 in $\alpha$-helix), which may contribute to its excellent thermostability. The good stability of McCut over a wide $\mathrm{pH}$ range, coupled with the excellent thermostability, makes it suitable for industrial use.

McCut displayed a wide range of substrate specificity with the highest activity towards $\mathrm{C}_{4}$ esters $p \mathrm{NPB}$ and tributyrin, which is consistent with that of other cutinases, such as Acut3-6hp from Arxula adeninivorans [8], CUTAB 1 from A. brassicicola [32], FsCut-6hp from F. solani f. sp. pisi [8], and TtCutA and TtCutB from $T$. terrestris $[11,12]$. In contrast, several cutinases are most active on shorter fatty acid esters, such as cutinases from Coprinopsis cinerea $\left(C_{3}\right.$, followed by $\left.C_{2}\right)$ [14] and S. conigenus $\left(\mathrm{C}_{2}\right.$, followed by $\left.\mathrm{C}_{3}\right)$ [34], while cutinases Acut1-6hp and Acut2-6hp from A. adeninivorans $\left(\mathrm{C}_{6}\right)$ prefer longer chain fatty acid esters [8]. In general, substrate preference towards short acyl chain length $(\leq 6)$ is a typical characteristic of cutinases, except $G$. cingulata cutinase, which preferentially hydrolyzes medium- and 

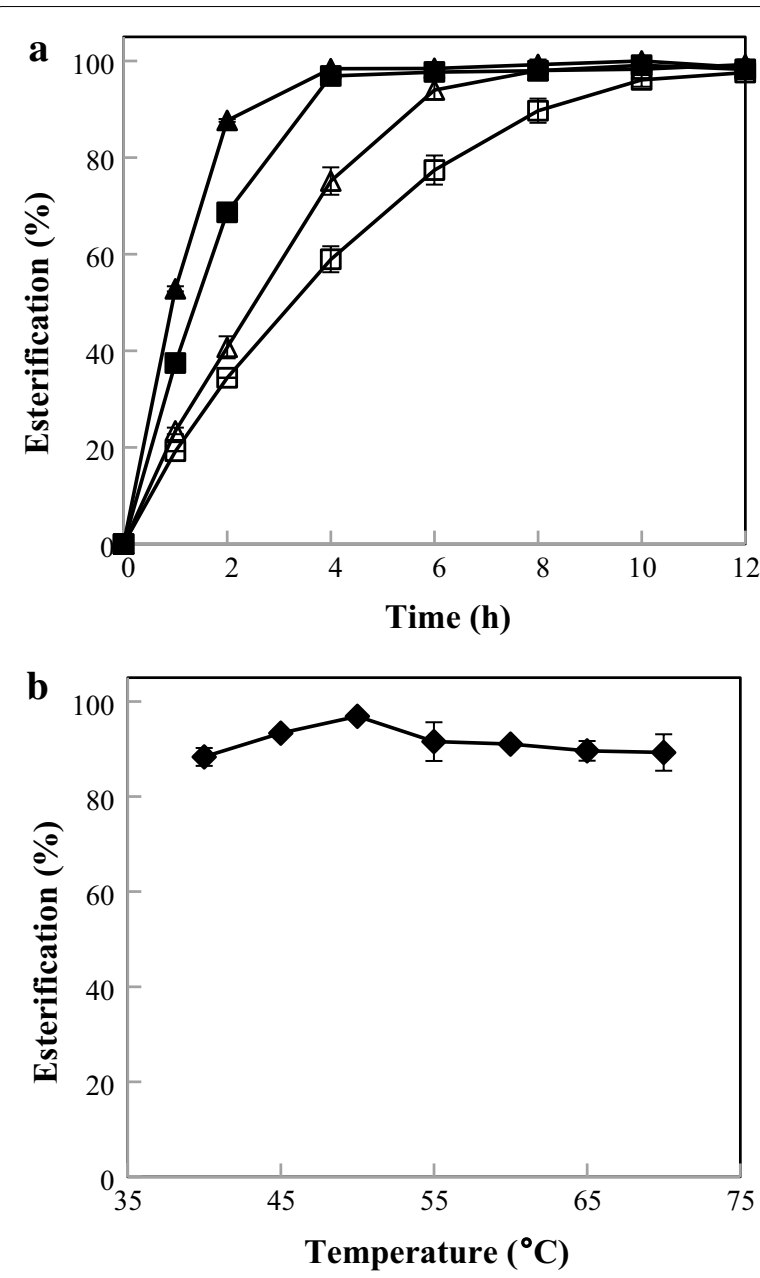

Fig. 6 Effects of enzyme dosage (a) and temperature (b) on butyl butyrate synthesis by McCut. In Fig. 4a, reactions were performed at $50^{\circ} \mathrm{C}, 200 \mathrm{rpm}$ for $12 \mathrm{~h}$, and enzyme dosages were $200 \mathrm{U} / \mathrm{mL}$ (open square), $300 \mathrm{U} / \mathrm{mL}$ (open triangle), $400 \mathrm{U} / \mathrm{mL}$ (filled square), and $600 \mathrm{U} / \mathrm{mL}$ (filled triangle). In Fig. 4b, reactions were conducted at $40-70{ }^{\circ} \mathrm{C}$ for $4 \mathrm{~h}$ with an enzyme dosage of $400 \mathrm{U} / \mathrm{mL}$. The values are the average of experiments performed in triplicate

long-chain $p N P$ esters $\left(C_{8}-C_{14}\right)$ [15]. It is worth noting that the specific activity of McCut towards various $p \mathrm{NP}$ esters did not show any significant decrease with carbon chain lengths increasing from 8 to 16 , which is distinguished from the behavior of most other cutinases [8, $11,12,14,34]$. The large and hydrophobic residues are crucial to increase the specificity of cutinases towards long-chain length substrates [9]. Hydrophobic aromatic residues Phe52, Tyr145, and Phe174 located close to the catalytic triad are important for the specificity of CLE towards the long-chain substrates [43], while superimposition of the structures of McCut and CLE showed that there is no hydrophobic aromatic residue in the catalytic groove in McCut. In addition, the space steric hindrance caused by Ser34 may lead to its preference for shortchain substrates.

McCut efficiently degraded cutin, the rate of which is higher than that of cutinases from T. terrestris $(3 \mu \mathrm{mol} / \mathrm{h} /$ $\mathrm{mg}$ protein) [12], and T. fusca $(4 \mu \mathrm{mol} / \mathrm{h} / \mathrm{mg}$ protein $)$ [35], but lower than LC-cutinase $(6 \mu \mathrm{mol} / \mathrm{h} / \mathrm{mg}$ protein $)$ from a metagenomics library [44]. McCut could hydrolyze aliphatic polyesters PCL and PBS. The hydrolysis efficiency of PCL by McCut is comparable to that of the cutinases from A. brassicicola (43\%) and F. solani (50\%) [38]. In contrast, AoCut and cutinases from A. fumigatus and $H$. insolens completely hydrolyzed PCL in $6 \mathrm{~h}$ [38]. The close distance between the two gatekeeper residues (Fig. 4c) and the space steric hindrance created by Ser34 (Fig. 4b) in McCut may explain its poor degradation ability on PCL in comparison with that of AoCut [22, 38]. A model for the binding of TfCut2 from T. fusca towards polymeric substrate indicated that an aromatic clamp formed by Tyr60 and Trp155 is a key element responsible for the high activity towards PET [27]. Therefore, no hydrophobic residue in catalytic groove may be the reason that McCut could not hydrolyze aromatic polyester PET.

Butyl butyrate is a valuable fuel source which possesses excellent compatibility with aviation kerosene, petrol, and diesel [2, 3]. To date, butyl butyrate has been successfully synthesized by several lipases through enzymatic routes [4-7]. Cutinases may be more attractive for butyl butyrate production since they prefer short-chain length substrates containing 4-6 carbon atoms and usually achieve high yields $[45,46]$. McCut displayed extremely good stability in the presence of alkanes (Table 1), which are commonly used as the reaction media in ester synthesis [47]. Furthermore, the preference of McCut for $\mathrm{C}_{4}$ substrates may also make it more suitable for butyl butyrate synthesis. Hence, the application potential of McCut in butyl butyrate was evaluated. McCut efficiently synthesized butyl butyrate with an esterification efficiency of $96.9 \%$, which is comparable to those of the cutinases from T. terrestris [11], Burkholderia cepacia [45], and $F$. solani pisi [46], as well as the lipases from Thermomyces lanuginosus [4] and Rhizomucor miehei [7]. Nevertheless, the reaction time of $4 \mathrm{~h}$ is much shorter than those obtained by other enzymes [4, 7, 11, 45]. Moreover, McCut exhibited excellent stability during reaction. Therefore, McCut may be a good candidate for in situ esterification for butyl butyrate production in biofuel industry.

\section{Conclusions}

A cutinase gene $(\mathrm{McCu})$ from $M$. cinnamomea was cloned and over-expressed in P. pastoris for the first time. The cutinase yield is the highest value obtained to date, 
indicating great potential for industrial production. The cutinase exhibited excellent $\mathrm{pH}$ and thermal stability, as well as broad substrate specificity. In addition, it synthesized butyl butyrate with high efficiency. These excellent properties make the cutinase potentially useful in butyl butyrate production in biofuel and chemical industries. Moreover, the structure of the enzyme provides valuable information for enhancing catalytic performance on polyesters, which may find use in biodegradation.

\section{Methods}

\section{Reagents}

T4 DNA ligase and restriction endonucleases were from New England Biolabs (Ipswich, MA, USA). LA Taq DNA polymerase was purchased from TaKaRa (Dalian, China). $p$-Nitrophenyl acetate ( $p \mathrm{NPA}), p \mathrm{NPB}, p$-nitrophenyl caprylate $(p \mathrm{NPC}), \quad p$-nitrophenyl decanoate $(p \mathrm{NPD})$, $p$-nitrophenyl laurate ( $p$ NPL), $p$-nitrophenyl myristate ( $p \mathrm{NPM}), p$-nitrophenyl palmitate ( $p \mathrm{NPP})$, and $p \mathrm{NP}$ were purchased from Sigma Chemical Company (St. Lous, MO, USA). $p$ NPH was from HEOWNS Company (Tianjin, China). All other chemicals used were of analytical grade unless otherwise stated.

\section{Strains and media}

Escherichia. coli strain $\mathrm{DH} 5 \alpha \quad\left[\mathrm{F}^{-}, \phi 80 \mathrm{~d}\right.$ lacZ $\Delta \mathrm{M} 15$, $\triangle\left(\right.$ lacZYA-argF) $\mathrm{U} 169, \operatorname{deo} R, \operatorname{rec} A 1$, endA1, hsdR17( $\mathrm{r}_{\mathrm{K}}^{-}$, $\left.\mathrm{m}_{\mathrm{K}}^{+}\right)$, phoA, supE44, $\lambda^{-}$, thi-1, gyrA96, relA1], and P. pastoris GS115 (his4) were used as hosts for gene cloning and expression, respectively. M. cinnamomea S168 was deposited in the China General Microbiological Culture Collection Center under Accession No. 6022. The liquid culture medium contained the following $(\mathrm{g} / \mathrm{L})$ : glutinous rice flour 15.0, tryptone 8.0, yeast extract 8.0, $\mathrm{KH}_{2} \mathrm{PO}_{4}$ 1.0, $\mathrm{NaCl} 0.5, \mathrm{MgSO}_{4} \cdot 7 \mathrm{H}_{2} \mathrm{O} 0.5, \mathrm{FeSO}_{4} \cdot 7 \mathrm{H}_{2} \mathrm{O} 0.01, \mathrm{CaCl}_{2}$ 0.2 , and $\mathrm{MnSO}_{4} \cdot 7 \mathrm{H}_{2} \mathrm{O} 0.05$, natural $\mathrm{pH}$.

Fermentation basal salts (FBS) medium contained the following (g/L): $\mathrm{CaSO}_{4}, 0.93 ; \mathrm{K}_{2} \mathrm{SO}_{4}, 18.2 ; \mathrm{MgSO}_{4} \cdot 7 \mathrm{H}_{2} \mathrm{O}$, 14.9; $\mathrm{KOH}, 4.13$; glycerol, 40.0; 85\% $\mathrm{H}_{3} \mathrm{PO}_{4}, 26.7 \mathrm{~mL} / \mathrm{L}$. $\mathrm{PTM}_{1}$ trace salts contained (g/L): $\mathrm{CuSO}_{4} \cdot 5 \mathrm{H}_{2} \mathrm{O}, 6.0 ; \mathrm{NaI}$, $0.08 ; \mathrm{MnSO}_{4} \cdot \mathrm{H}_{2} \mathrm{O}, 3.0 ; \mathrm{Na}_{2} \mathrm{MoO}_{4} \cdot 2 \mathrm{H}_{2} \mathrm{O}, 0.2 ; \mathrm{H}_{3} \mathrm{BO}_{3}$, 0.02; $\mathrm{CoCl}_{2}, 0.5 ; \mathrm{ZnCl}_{2}, 20.0 ; \mathrm{FeSO}_{4} \cdot 7 \mathrm{H}_{2} \mathrm{O}, 65.0$; biotin, 0.2 ; and $\mathrm{H}_{2} \mathrm{SO}_{4}, 5.0 \mathrm{~mL} / \mathrm{L}$.

\section{Cloning and sequence analysis of a cutinase gene}

For isolation of genomic DNA, M. cinnamomea S168 was cultured at $37^{\circ} \mathrm{C}$ for 3 days with a rotation speed of $200 \mathrm{rpm}$. Fungal mycelia were collected by centrifugation at $11,510 \mathrm{~g}$ for $10 \mathrm{~min}$, then washed twice with sterilized water, and ground to powder in liquid nitrogen. The genomic DNA was extracted using a Fungal DNA Midi Kit (Omega Biotek, Doraville, GA, USA). The total RNA was isolated with Trizol reagent (Invitrogen, Carlsbad,
USA) and mRNAs were purified using the Oligotex mRNA Midi kit (Qiagen, Germany). First and second strands of cDNA were synthesized using PrimeScript ${ }^{\mathrm{TM}}$ RT-PCR Kit (TaKaRa, Tokyo, Japan).

The specific primers McCutF (5'-ATGAAGATC CAATTTGTTATTTCCGC-3') and McCutR (5'-TTAC GAGAGTCTATCCTCAAGCC-3') were designed. To obtain the full-length gene and coding sequence, PCR was performed using genomic DNA and cDNA as templates, respectively. PCR conditions were as follows: a hot start at $94{ }^{\circ} \mathrm{C}$ for $5 \mathrm{~min}, 35$ cycles of $94{ }^{\circ} \mathrm{C}$ for $30 \mathrm{~s}, 54{ }^{\circ} \mathrm{C}$ for $30 \mathrm{~s}$, and $72{ }^{\circ} \mathrm{C}$ for $60 \mathrm{~s}$, followed by a final extension step at $72{ }^{\circ} \mathrm{C}$ for $10 \mathrm{~min}$. After amplification, PCR products were purified, ligated to pMD18-T vector, and sequenced.

Homology searches of nucleotides were performed using BLAST at the NCBI. Multiple alignment analysis of the amino acid sequences was carried out using the ClustalW2.0 (http://www.ebi.ac.uk/Tools/clustalw2/ index.html). The signal peptide and conserved domains were analyzed at Signal P 4.1 server (http://www.cbs. dtu.dk/services/SignalP/) and ScanProsite (http://www. expasy.ch/tools/ScanProsite), respectively. $N$-Glycosylation sites were predicted using NetNGlyc 1.0 (http:// www.cbs.dtu.dk/services/NetNGlyc/).

\section{Transformation of $P$. pastoris and expression in shake-flask}

The specific primers McCutEcoRIF (5'-tgcgaGAAT TCTCCCCAGTTGCAGTGGAGA- $3^{\prime}$ ) and McCutNotIR (5'-tgcgaGCGGCCGCT TACGAGAGTCTATCC T CAAGCC-3'), with EcoRI and NotI sites (underlined), respectively, were used to amplify the coding region of the cutinase gene without the signal peptide sequence. PCR amplification was carried out using CDNA as the template. After digestion with EcoRI and NotI, the purified PCR product was inserted into PPIC9K, yielding the recombinant plasmid pPIC9K-McCut. The recombinant plasmid was linearized with SalI and then transformed into P. pastoris GS115 by electroporation. The transformants were plated on MD (minimal dextrose) plates and incubated at $30{ }^{\circ} \mathrm{C}$ for $2-3$ days. To screen multiple inserts, the colonies from MD plates were plated on YPD-G418 plates with G418 concentrations of 1.0, 2.0, 4.0, and $6.0 \mathrm{mg} / \mathrm{mL}$. Then G418 resistant colonies were tested for the expression of cutinase using BMGY/ BMMY according to Multi-copy Pichia Expression Kit (Invitrogen Inc.). After induction by methanol for 3 days, the crude enzyme was used for cutinase activity analysis.

\section{High-cell density fermentation}

For scale-up cutinase production, the transformant showing the highest cutinase activity in shake-flask culture was cultivated in a 5 - $\mathrm{L}$ fermentor with $1.5 \mathrm{~L}$ working 
volume at $30{ }^{\circ} \mathrm{C}$. The fermentation process including glycerol batch phase, glycerol fed-batch phase, and methanol fed-batch phase was performed according to Pichia Fermentation Guidelines (Version B, 053002, Invitrogen Inc.). The fermentation medium for cutinase production in the fermentor was FBS medium containing $4.35 \mathrm{~mL} / \mathrm{L}$ of $\mathrm{PTM}_{1}$ trace salts. Throughout the cultivation period, the dissolved oxygen level was maintained above $20 \%$ by adjusting the air flow rate and agitation speed. The initial $\mathrm{pH}$ was controlled at 4.0 by ammonium hydroxide. Upon depletion of initial glycerol, fed-batch fermentation was initiated with the addition of $50 \%(\mathrm{w} / \mathrm{v})$ glycerol containing $12 \mathrm{~mL} / \mathrm{L} \mathrm{PTM}_{1}$ trace salts at a rate of $18.4 \mathrm{~mL} / \mathrm{h} / \mathrm{L}$ (initial medium volume). After a 6-h glycerol fed-batch phase, the methanol induction phase was started with the addition of $100 \%$ methanol containing $12 \mathrm{~mL} / \mathrm{L} \mathrm{PTM}_{1}$ trace salts at a flow rate of $10 \mathrm{~mL} / \mathrm{h} / \mathrm{L}$ (initial medium volume), and the medium $\mathrm{pH}$ was adjusted to 6.0. During the methanol induction phase, samples were withdrawn every $12 \mathrm{~h}$, and dcw, cutinase activity, and protein content were determined. The cell-surface cutinase activity on $P$. pastoris cell wall was measured by the method of $\mathrm{Su}$ et al. [48]. The cells were collected by centrifugation at $11,510 \mathrm{~g}$ for $10 \mathrm{~min}$, washed three times with distilled water, and resuspended in $50 \mathrm{mM}$ Tris- $\mathrm{HCl} \mathrm{pH} \mathrm{8.0,} \mathrm{and}$ the activity of the suspended solution was then assayed according to the standard method. The dry cell weight (dcw) was quantified by drying the washed cells until a constant weight was achieved.

\section{Enzyme assay and protein determination}

Cutinase activity was assayed by the method of Xu et al. [11] using $p \mathrm{NPB}$ as a substrate. The reaction mixture $(500 \mu \mathrm{L})$ contained $400 \mu \mathrm{L} 50 \mathrm{mM}$ Tris- $\mathrm{HCl}$ buffer $\mathrm{pH}$ 8.0, $50 \mu \mathrm{L}$ suitably diluted enzyme, and $50 \mu \mathrm{L} 20 \mathrm{mM}$ $p$ NPB dissolved in isopropanol. After reaction for $10 \mathrm{~min}$ at $45^{\circ} \mathrm{C}$, the released $p \mathrm{NP}$ was quantified by measuring the absorbance at $410 \mathrm{~nm}$. One unit of enzyme activity was defined as the amount of enzyme liberating $1 \mu \mathrm{mol}$ $p$ NP per min under the above conditions. Protein concentration was determined according to the method of Lowry et al. [49], using bovine serum albumin as the standard.

\section{Purification of McCut}

The crude enzyme was collected by centrifuging the fermentation culture at $11,510 \mathrm{~g}$ for $10 \mathrm{~min}$. After dialysis against $20 \mathrm{mM}$ phosphate buffer $\mathrm{pH} 8.0$ (buffer A) for $16 \mathrm{~h}$, the crude enzyme was loaded onto a Q Sepharose Fast Flow column equilibrated with buffer $\mathrm{A}$ at a flow rate of $0.5 \mathrm{~mL} / \mathrm{min}$. After washing with buffer A, the bound proteins were eluted with a linear $\mathrm{NaCl}$ gradient from 0 to $500 \mathrm{mM}$ in buffer $\mathrm{B}$ ( $20 \mathrm{mM}$ phosphate buffer $\mathrm{pH} 8.0$ ) at $1 \mathrm{~mL} / \mathrm{min}$. The fractions with cutinase activity were checked for purity by SDS-PAGE.

\section{Crystallization, data collection, and structure determination}

Crystallization experiments were set up using the sittingdrop vapor diffusion method according to Qin et al. [50]. Crystals suitable for diffraction were grown in drops containing $0.2 \mathrm{M} \mathrm{KCl}$ and $20 \%$ polyethylene glycol 3350 . Diffraction data of McCut were collected at beamline BL17U at Shanghai Synchrotron Research Facility (SSRF). The data were indexed, integrated, and scaled using the program $H K L-2000$ [51].

The structure of McCut was determined by molecular replacement using the coordinates of $A$. oryzae cutinase (PDB ID: 3GBS). The structure model was built and refined with the Phenix suite [52]. The detailed statistics of data collection and refinement are shown in Table 4.

\section{Biochemical properties of McCut}

The optimal $\mathrm{pH}$ of McCut was determined in the $\mathrm{pH}$ range of 3.0-11.0. The buffers used were citrate $(\mathrm{pH}$ 3.0-6.0), phosphate ( $\mathrm{pH} 6.0-8.0)$, Tris- $\mathrm{HCl}(\mathrm{pH} 7.0-$ 9.0), 4-(2-hydroxyethyl)-1-piperazineethanesulfonic acid (HEPES, $\mathrm{pH} 7.0-8.0)$, Tricine $(\mathrm{pH} 7.5-8.5)$, and 2-(cyclohexylamino) ethanesulfonic acid (CHES, pH 8.010.0). For the determination of $\mathrm{pH}$ stability, the enzyme was incubated at $50{ }^{\circ} \mathrm{C}$ for $30 \mathrm{~min}$ in the above buffers. After cooling on ice for $30 \mathrm{~min}$, the residual activity was measured at $45^{\circ} \mathrm{C}$ in $50 \mathrm{mM}$ Tris- $\mathrm{HCl}$ buffer $\mathrm{pH} 8.0$.

The optimal temperature for cutinase activity was evaluated by measuring its activity at different temperatures $\left(20-55^{\circ} \mathrm{C}\right)$ in $50 \mathrm{mM}$ Tris- $\mathrm{HCl}$ buffer $\mathrm{pH}$ 8.0. To determine its thermostability, the residual activity was assayed after incubation of the cutinase at $30-100{ }^{\circ} \mathrm{C}$ for $30 \mathrm{~min}$ in $50 \mathrm{mM}$ Tris- $\mathrm{HCl}$ buffer $\mathrm{pH}$ 8.0. The denaturation halflives of McCut at $70,75,80$, and $85^{\circ} \mathrm{C}$ were measured by incubating the cutinase at the mentioned temperatures in $50 \mathrm{mM}$ Tris- $\mathrm{HCl} \mathrm{pH} 8.0$ for $6 \mathrm{~h}$. Samples were taken at intervals, and the residual activity was determined after cooling for $30 \mathrm{~min}$.

The influence of organic solvents and surfactants on enzyme activity was tested by mixing cutinase with various organic solvents and surfactants at the final concentrations of $30 \%(\mathrm{v} / \mathrm{v})$ and $5 \%(\mathrm{v} / \mathrm{v})$, respectively. After incubation in $50 \mathrm{mM}$ Tris- $\mathrm{HCl}$ buffer $\mathrm{pH} 8.0$ at $50^{\circ} \mathrm{C}$ for $1 \mathrm{~h}$, the residual activity was measured by the method as described above.

\section{Substrate specificity and kinetic parameters of McCut}

The specificity of McCut towards various $p$ NP esters and triglycerides was tested at $45^{\circ} \mathrm{C}$ in $50 \mathrm{mM}$ Tris- $\mathrm{HCl}$ buffer $\mathrm{pH} 8.0$ by the method of Yang et al. [12]. 
Table 4 X-ray data collection and refinement statistics

\begin{tabular}{|c|c|}
\hline McCut & \\
\hline \multicolumn{2}{|l|}{ Data collection statistics } \\
\hline Radiation source & SSRF-BL17U \\
\hline Wavelength $(\AA)$ & 0.9792 \\
\hline Resolution ( $\AA$ ) & $28.3-1.76(1.823-1.76)$ \\
\hline Space group & $P 2,22_{1}$ \\
\hline \multicolumn{2}{|l|}{ Unit cell parameters } \\
\hline$a, b, c(\AA)$ & $34.4,37.8,128.0$ \\
\hline$a, \beta, \gamma\left(^{\circ}\right)$ & $90,90,90$ \\
\hline Protein molecules in asymmetric unit & 1 \\
\hline Unique reflections & $16,910(1626)$ \\
\hline Completeness (\%) & 98.0 \\
\hline$R_{\text {merge }}^{\mathrm{a}}(\%)$ & $6.8(11.8)$ \\
\hline Wilson B-factor $\left(\AA^{2}\right)$ & 15.65 \\
\hline \multicolumn{2}{|l|}{ Refinement statistics } \\
\hline Resolution ( $(\AA)$ & 1.76 \\
\hline$R_{\text {work }}^{\mathrm{b}}(\%)$ & $0.1717(0.1744)$ \\
\hline$R_{\text {free }}^{\mathrm{b}}(\%)$ & $0.1754(0.1619)$ \\
\hline \multicolumn{2}{|l|}{ RMSD } \\
\hline Bond lengths ( $\AA$ ) & 0.006 \\
\hline Bond angles $\left(^{\circ}\right)$ & 0.85 \\
\hline Average B-factors $\left(\AA^{2}\right)$ & 13.44 \\
\hline Macromolecules & 11.66 \\
\hline Ligands & - \\
\hline Solvent & 24.57 \\
\hline \multicolumn{2}{|l|}{ Ramachandran } \\
\hline Most favored regions (\%) & 97 \\
\hline Additional allowed regions (\%) & 2.2 \\
\hline Disallowed regions (\%) & 0 \\
\hline Clashscore & 2.22 \\
\hline PDB code & $5 \times 88$ \\
\hline
\end{tabular}

${ }^{a} R_{\text {merge }}=\sum_{h k l} \sum_{i}|l i(h k l)-\langle l(h k l)\rangle| / \sum_{h k l} \sum_{i} l i(h k l)$, where li(hkl) is the ith observation of reflection $h k l$ and $/(h k l)$ is the weighted average intensity for all observations $i$ of reflection $h k l$

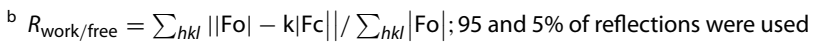
for $R_{\text {work }}$ and $R_{\text {free, }}$ respectively

The kinetic parameters, $K_{\mathrm{m}}$ and $V_{\max }$ of McCut towards $p \mathrm{NPB}$ and $p \mathrm{NPH}$ were determined using different substrate concentrations at $45{ }^{\circ} \mathrm{C}$ in $50 \mathrm{mM}$ Tris- $\mathrm{HCl}$ buffer $\mathrm{pH} 8.0$ for $5 \mathrm{~min}$. The $K_{\mathrm{m}}$ and $V_{\max }$ were calculated using the software GraFit.

\section{Degradation of polymers by McCut}

The hydrolysis property of McCut on apple cutin was performed at $45^{\circ} \mathrm{C}$ in $25 \mathrm{mM}$ Tris- $\mathrm{HCl} \mathrm{pH} 8.0$ according to the method of Yang et al. [12].

The degradation of synthetic polyesters PCL, PBS, and PET was determined by the method of Liu et al. [22]. Approximately $35 \mathrm{mg}$ polyesters were added into $2.5 \mathrm{~mL}$
$100 \mathrm{mM}$ Tris- $\mathrm{HCl} \mathrm{pH} 8.0$ with a concentration of $0.5 \mathrm{mg}$ cutinase and incubated at $45^{\circ} \mathrm{C}, 200 \mathrm{rpm}$ for $12 \mathrm{~h}$. Weight losses of polyesters were calculated after drying.

\section{Synthesis of butyl butyrate by McCut}

The synthetic reactions by McCut were carried out in $5 \mathrm{~mL}$ isooctane containing $0.1 \mathrm{M}$ butyric acid, $0.2 \mathrm{M}$ butanol, $200-600 \mathrm{U} / \mathrm{mL}$ of spray-dried cutinase powder, and $40 \mathrm{mg} / \mathrm{mL}$ molecular sieve $4 \AA$. The mixtures were incubated at $40-70{ }^{\circ} \mathrm{C}$ with constant shaking at $200 \mathrm{rpm}$.

The periodically withdrawn samples were analyzed using a gas chromatograph (Agilent 6890, HewlettPackard Co., Avondale, PA, USA), equipped with a flame ionization detector and an HP-INNOWax column $(30 \mathrm{~m} \times 0.32 \mathrm{~mm} \times 0.25 \mu \mathrm{m})$. The carrier gas used was nitrogen. The temperatures of both injector and detector were maintained at $250{ }^{\circ} \mathrm{C}$. The oven temperature was held at $50{ }^{\circ} \mathrm{C}$ for $3 \mathrm{~min}$ and then increased to $220^{\circ} \mathrm{C}$ at a rate of $15^{\circ} \mathrm{C} / \mathrm{min}$ and held for $2 \mathrm{~min}$.

The stability of McCut under the optimal reaction conditions (in isooctane containing $0.1 \mathrm{M}$ butyric acid and $0.2 \mathrm{M}$ butanol with an incubation temperature of $50{ }^{\circ} \mathrm{C}$ ) was determined. Samples withdrawn at 1,2 , and $4 \mathrm{~h}$ were centrifuged at $11,510 \mathrm{~g}$ for $10 \mathrm{~min}$, and the precipitates (cutinase) were dissolved in $50 \mathrm{mM}$ Tris $-\mathrm{HCl} \mathrm{pH} \mathrm{8.0.}$ The residual activity was determined at $45{ }^{\circ} \mathrm{C}$ in $50 \mathrm{mM}$ Tris- $\mathrm{HCl} \mathrm{pH} \mathrm{8.0.}$

\begin{abstract}
Abbreviations
pNP: $p$-nitrophenol; $p N P A: p$-nitrophenyl acetate; $p N P B$ : $p$-nitrophenyl butyrate; pNPC: $p$-nitrophenyl caprylate; $p N P D$ : $p$-nitrophenyl decanoate; $p N P L$ : $p$-nitrophenyl laurate; $p N P M$ : $p$-nitrophenyl myristate; $p N P P$ : $p$-nitrophenyl palmitate; $p \mathrm{NPH}$ : $p$-nitrophenyl hexanoate; MD: minimal dextrose; BMGY: buffered minimal glycerol complex medium; BMMY: buffered minimal methanol complex medium; HEPES: 4-(2-hydroxyethyl)-1-piperazineethanesulfonic acid; CHES: 2-(cyclohexylamino) ethanesulfonic acid.
\end{abstract}

\section{Authors' contributions}

$X D, Y L, X Y$, and $S X Y$ participated in the design of the study, carried out the experiments, organized and interpreted the data, and drafted the manuscript. XD performed the fermentation, hydrolysis, and synthesis experiments. $Y L$ performed the gene cloning, expression, and the amino acid sequence alignment. XY performed the crystallization experiments and structure determination. ZJ and SQY participated in the design, coordination, and data analysis of the study, and corrected the manuscript. All authors read and approved the final manuscript.

\section{Author details \\ ${ }^{1}$ Beijing Advanced Innovation Center for Food Nutrition and Human Health, China Agricultural University, Beijing 100083, China. ${ }^{2}$ College of Food Science and Nutritional Engineering, China Agricultural University, Beijing 100083, China. ${ }^{3}$ College of Engineering, China Agricultural University, Beijing 100083, China. ${ }^{4}$ Beijing Key Laboratory of Flavor Chemistry, Beijing Technology and Business University (BTBU), Beijing 100048, China.}

\section{Acknowledgements}

This work was supported by the National Natural Science Foundation of China (No. 31371718), the National Science Fund for Distinguished Young Scholars (No. 31325021), and Open Project Program of Beijing Key Laboratory of Flavor Chemistry, Beijing Technology and Business University (BTBU). 


\section{Competing interests}

The authors declare that they have no competing interests.

\section{Publisher's Note}

Springer Nature remains neutral with regard to jurisdictional claims in published maps and institutional affiliations.

Received: 18 May 2017 Accepted: 11 September 2017

Published online: 19 September 2017

\section{References}

1. Yan Q, Duan X, Liu Y, Jiang Z, Yang S. Expression and characterization of a novel 1,3-regioselective cold-adapted lipase from Rhizomucor endophyticus suitable for biodiesel synthesis. Biotechnol Biofuels. 2016:9:86.

2. Jenkins RW, Munro M, Nash S, Chuck CJ. Potential renewable oxygenated biofuels for the aviation and road transport sectors. Fuel. 2013;103:593-9.

3. Chuck CJ, Donnelly J. The compatibility of potential bioderived fuels with Jet A-1 aviation kerosene. Appl Energy. 2014;118:83-91.

4. Martins AB, Friedrich JLR, Cavalheiro JC, Garcia-Galan C, Barbosa O, Ayub MAZ, Fernandez-Lafuente R, Rodrigues RC. Improved production of butyl butyrate with lipase from Thermomyces lanuginosus immobilized on styrene-divinylbenzene beads. Bioresour Technol. 2013;134:417-22.

5. Xin F, Basu A, Yang KL, He J. Strategies for production of butanol and butyl-butyrate through lipase-catalyzed esterification. Bioresour Technol. 2016:202:214-9.

6. Zhang ZT, Taylor S, Wang Y. In situ esterification and extractive fermentation for butyl butyrate production with Clostridium tyrobutyricum. Biotechnol Bioeng. 2017:9999:1-10.

7. Lorenzoni ASG, Graebin NG, Martins AB, Fernandez-Lafuente R, Ayub $M A Z$, Rodrigues RC. Optimization of pineapple flavour synthesis by esterification catalyzed by immobilized lipase from Rhizomucor miehei. Flavour Fragr J. 2012;27:196-200.

8. Bischoff F, Litwińska K, Cordes A, Baronian K, Bode R, Schauer F, Kunze G. Three new cutinases from the yeast Arxula adeninivorans that are suitable for biotechnological applications. Appl Environ Microbiol. 2015:81:5497-510.

9. Chen S, Su L, Chen J, Wu J. Cutinase: characteristics, preparation, and application. Biotechnol Adv. 2013;31:1754-67.

10. Kold D, Dauter Z, Laustsen AK, Brzozowski AM, Turkenburg JP, Nielsen AD, Kolds H, Petersen E, Schiøtt B, Maria LD, Wilson KS, Svendsen A, Wimmer R. Thermodynamic and structural investigation of the specific SDS binding of Humicola insolens cutinase. Protein Sci. 2014;23:1023-35.

11. Xu H, Yan Q, Duan X, Yang S, Jiang Z. Characterization of an acidic coldadapted cutinase from Thielavia terrestris and its application in flavor ester synthesis. Food Chem. 2015;188:439-45.

12. Yang $S, X u H$, Yan Q, Liu Y, Zhou P, Jiang Z. A low molecular mass cutinase of Thielavia terrestris efficiently hydrolyzes poly(esters). J Ind Microbiol Biotechnol. 2013:40:217-26.

13. Calado CRC, Ferreira BS, da Fonseca MMR, Cabral JMS, Fonseca LP. Integration of the production and the purification processes of cutinase secreted by a recombinant Saccharomyces cerevisiae SU50 strain. J Biotechnol. 2004;109:147-58.

14. Kontkanen H, Westerholm-Parvinen A, Saloheimo M, Saloheimo M, Bailey M, Ratto M, Mattila I, Mohsina M, Kalkkinen N, Nakari-Setala T, Buchert J. Novel Coprinopsis cinerea polyesterase that hydrolyzes cutin and suberin. Appl Environ Microbiol. 2009;75:2148-57.

15. Seman WMKW, Bakar SA, Bukhari NA, Gaspar SM, Othman R, Nathan S, Mahadi NM, Jahim J, Murad AMA, Bakar FDA. High level expression of Glomerella cingulata cutinase in dense cultures of Pichia pastoris grown under fed-batch conditions. J Biotechnol. 2014;184:219-28.

16. Su L, Hong R, Wu J. Enhanced extracellular expression of gene-optimized Thermobifida fusca cutinase in Escherichia coli by optimization of induction strategy. Process Biochem. 2015;50:1039-46.

17. Spohner SC, Müller H, Quitmann H, Czermak P. Expression of enzymes for the usage in food and feed industry with Pichia pastoris. J Biotechnol. 2015;202:118-34.
18. Prabhu AA, Veeranki VD, Dsilva SJ. Improving the production of human interferon gamma (hIFN- $\gamma$ ) in Pichia pastoris cell factory: an approach of cell level. Process Biochem. 2016:51:709-18.

19. Prabhu AA, Mandal B, Dasu W. Medium optimization for high yield production of extracellular human interferon- $\gamma$ from Pichia pastoris: a statistical optimization and neural network-based approach. Korean J Chem Eng. 2017;34:1109-21.

20. Martinez C, Geus PD, Lauwereys M, Matthyssens G, Cambillau C. Fusarium solani cutinase is a lipolytic enzyme with a catalytic serine accessible to solvent. Nature. 1992;356:615-8.

21. Longhi S, Cambillau C. Structure-activity of cutinase, a small lipolytic enzyme. Biochim Biophys Acta. 1999;1441:185-96.

22. Liu Z, Gosser Y, Baker PJ, Ravee Y, Lu Z, Alemu G, Li H, Butterfoss GL, Kong XP, Gross R, Montclare JK. Structural and functional studies of Aspergillus oryzae cutinase: enhanced thermostability and hydrolytic activity of synthetic ester and polyester degradation. J Am Chem Soc. 2009;131:15711-6.

23. Dimarogona M, Nikolaivits E, Kanelli M, Christakopoulos P, Sandgren M, Topakas E. Structural and functional studies of a Fusarium oxysporum cutinase with polyethylene terephthalate modification potential. Biochim Biophys Acta General Subj. 2015;1850:2308-17.

24. Nyon MP, Rice DW, Berrisford JM, Hounslow AM, Moir AJG, Huang H, Nathan S, Mahadi NM, Bakar FDA, Craven CJ. Catalysis by Glomerella cingulata cutinase requires conformational cycling between the active and inactive states of its catalytic triad. J Mol Biol. 2009;385:226-35.

25. Roussel A, Amara S, Nyyssölä A, Diaz EM, Blangy S, Kontkanen H, Parvinen AW, Carrière F, Cambillau C. A cutinase from Trichoderma reesei with a lid-covered active site and kinetic properties of true lipases. J Mol Biol. 2014:426:3757-72

26. Kitadokoro K, Thumarat U, Nakamura R, Nishimura K, Karatani H, Suzuki $\mathrm{H}$, Kawai F. Crystal structure of cutinase Est119 from Thermobifida alba AHK119 that can degrade modified polyethylene terephthalate at 1.76 angstrom resolution. Polym Degrad Stab. 2012;97:771-5.

27. Roth C, Wei R, Oeser T, Then J, Föllner C, Zimmermann W, Sträter N. Structural and functional studies on a thermostable polyethylene terephthalate degrading hydrolase from Thermobifida fusca. Appl Microbiol Biotechnol. 2014:98:7815-23.

28. Han P, Zhou P, Hu S, Yang S, Yan Q, Jiang Z. A novel multifunctional a-amylase from the thermophilic fungus Malbranchea cinnamomea: biochemical characterization and three-dimensional structure. Appl Biochem Biotechnol. 2013;170:420-35.

29. Fan G, Yang S, Yan Q, Guo Y, Li Y, Jiang Z. Characterization of a highly thermostable glycoside hydrolase family 10 xylanase from Malbranchea cinnamomea. Int J Biol Macromol. 2014;70:482-9.

30. Mahajan C, Basotra N, Singh S, Di Falco M, Tsang A, Chadha BS. Malbranchea cinnamomea: a thermophilic fungal source of catalytically efficient lignocellulolytic glycosyl hydrolases and metal dependent enzymes. Bioresour Technol. 2016:200:55-63.

31. Dutta K, Sen S, Veeranki VD. Production, characterization and application of microbial cutinases. Process Biochem. 2009;44:127-34.

32. Koschorreck K, Liu D, Kazenwadel C, Schmid RD, Hauer B. Heterologous expression, characterization and site-directed mutagenesis of cutinase CUTAB 1 from Alternaria brassicicola. Appl Microbiol Biotechnol. 2010;87:991-7

33. Nyyssölä A, Pihlajaniemi V, Järvinen R, Mikander S, Kontkanen H, Kruus K, Kallio H, Buchert J. Screening of microbes for novel acidic cutinases and cloning and expression of an acidic cutinase from Aspergillus niger CBS 513.88. Enzyme Microb Technol. 2013;52:272-8.

34. Nyyssölä A, Pihlajaniemi V, Häkkinen M, Kontkanen $H$, Saloheimo M, Nakari-Setälä T. Cloning and characterization of a novel acidic cutinase from Sirococcus conigenus. Appl Microbiol Biotechnol. 2014;98:3639-50.

35. Chen S, Tong X, Woodard RW, Du G, Wu J, Chen J. Identification and characterization of bacterial cutinase. J Biol Chem. 2008;283:25854-62.

36. Bermúdez-García E, Peña-Montes C, Castro-Rodríguez JA, González-Canto A, Navarro-Ocaña A, Farrés A. ANCUT2, a thermo-alkaline cutinase from Aspergillus nidulans and its potential application. Appl Biochem Biotechnol. 2017. doi:10.1007/s12010-016-2378-z.

37. Thumarat U, Kawabata T, Nakajima M, Nakajima H, Sugiyama A, Yazaki K, Tada T, Waku T, Tanaka N, Kawai F. Comparison of genetic structures and biochemical properties of tandem cutinase-type polyesterases from Thermobifida alba AHK119. J Biosci Bioeng. 2015;120:491-7. 
38. Baker PJ, Poultney C, Liu Z, Gross R, Montclare JM. Identification and comparison of cutinases for synthetic polyester degradation. Appl Microbiol Biotechnol. 2012;93:229-40.

39. Vieille C, Zeikus GJ. Hyperthermophilic enzymes: sources, uses, and molecular mechanisms for thermostability. Microbiol Mol Biol Rev. 2001;65:1-43.

40. $\mathrm{Yu} \mathrm{H}$, Huang $\mathrm{H}$. Engineering proteins for thermostability through rigidifying flexible sites. Biotechnol Adv. 2014;32:308-15.

41. Shirke AN, Basore D, Butterfoss GL, Bonneau R, Bystroff C, Gross RA. Toward rational thermostabilization of Aspergillus oryzae cutinase: insights into catalytic and structural stability. Proteins Struct Funct Bioinform. 2016;84:60-72.

42. Thumarat U, Nakamura R, Kawabata T, Suzuki H, Kawai F. Biochemical and genetic analysis of a cutinase-type polyesterase from a thermophilic Thermobifida alba AHK119. Appl Microbiol Biotechnol. 2012;95:419-30.

43. Kodama Y, Masaki K, Kondo H, Suzuki M, Tsuda S, Nagura T, Shimba N, Suzuki E, lefuji H. Crystal structure and enhanced activity of a cutinaselike enzyme from Cryptococcus sp. strain S-2. Proteins Struct Funct Bioinform. 2009;77:710-7.

44. Sulaiman S, Yamato S, Kanaya E, Kim JJ, Koga Y, Takano K, Kanaya S. Isolation of a novel cutinase homolog with polyethylene terephthalatedegrading activity from leaf-branch compost by using a metagenomic approach. Appl Environ Microbiol. 2012;78:1556-62.

45. Dutta K, Dasu W. Synthesis of short chain alkyl esters using cutinase from Burkholderia cepacia NRRL B2320. J Mol Catal B Enzym. 2011;72:150-6.
46. De Barros DPC, Azevedo AM, Cabral JMS, Fonseca LP. Optimization of flavor esters synthesis by Fusarium Solani pisi cutinase. J Food Biochem. 2012;36:275-84.

47. Dhake KP, Thakare DD, Bhanage BM. Lipase: a potential biocatalyst for the synthesis of valuable flavor and fragrance ester compounds. Flavour Frag J. 2012;28:71-83.

48. Su GD, Huang DF, Han SY, Zheng SP, Lin Y. Display of Candida antarctica lipase B on Pichia pastoris and its application to flavor ester synthesis. Appl Microbiol Biotechnol. 2010;86:1493-501.

49. Lowry OH, Rosebrough NJ, Farr AL, Randall RJ. Protein measurement with the folin phenol reagent. J Biol Chem. 1951;193:265-75.

50. Qin Z, Yan Q, Yang S, Jiang Z. Modulating the function of a $\beta-1,3-$ glucanosyltransferase to that of an endo- $\beta-1,3-$ glucanase by structurebased protein engineering. Appl Microbiol Biotechnol. 2016;100:1765-76.

51. Otwinowski Z, Minor W. Processing of X-ray diffraction data collected in oscillation mode, macromolecular crystallography. Methods Enzymol. 1997;276:307-26.

52. Adams PD, Afonine PV, Bunkoczi G, Chen VB, Davis IW, Echol N, Headd JJ, Hung LW, Kapral GJ, Grosse-Kunstleve RW, McCoy AJ, Moriarty NW, Oeffner R, Read RJ, Richardson DC, Richardson JS, Terwilliger TC, Zwart PH. PHENIX: a comprehensive Python-based system for macromolecular structure solution. Acta Crystallogr Sect D Biol Crystallogr. 2010;66:213-21.

\section{Submit your next manuscript to BioMed Central and we will help you at every step:}

- We accept pre-submission inquiries

- Our selector tool helps you to find the most relevant journal

- We provide round the clock customer support

- Convenient online submission

- Thorough peer review

- Inclusion in PubMed and all major indexing services

- Maximum visibility for your research

Submit your manuscript at www.biomedcentral.com/submit
() BioMed Central 